\title{
The Politics of Intersectionality
}

The Politics of Intersectionality series builds on the longstanding insights of intersectionality theory from a vast variety of disciplinary perspectives. As a globally utilized analytical framework for understanding issues of social justice, Leslie McCall, Mary Hawkesworth, Michelle Berger, and others argue that intersectionality is arguably the most important theoretical contribution of women's and gender studies to date. Indeed, the imprint of intersectional analysis can be easily found on innovations in equality legislation, human rights, and development discourses.

The history of what is now called "intersectional thinking" is long. In fact, prior to its mainstreaming, intersectionality analysis was carried for many years mainly by black and other racialized women who, from their situated gaze, perceived as absurd, not just misleading, any attempt by feminists and others to homogenize women's situation, particularly in conceptualizing such situations as analogous to that of racialized others. As Brah and Phoenix point out, many black feminists fulfilled significant roles in the development of intersectional analysis, such as the Combahee River Collective, the black lesbian feminist organization from Boston, which pointed out the need of developing an integrated analysis and practice based upon the fact that major systems of oppression interlock rather than operate separately. However, the term "intersectionality" itself emerged nominally from the field of critical legal studies, where critical race feminist Kimberle Williams Crenshaw wrote two pathbreaking articles, "Demarginalizing the Intersection of Race and Sex: A Critique of Antidiscrimination Doctrine, Feminist Theory and Antiracist Politics" and "Mapping the Margins: Intersectionality, Identity Politics, and Violence Against Women of Color." At nearly the same time, social theorist Patricia Hill Collins was preparing her landmark work, "Black Feminist Thought: Knowledge, Consciousness and the Politics of Empowerment," which characterized intersections of race, class, and gender as mutually reinforcing sites of power relations.

Both Crenshaw and Collins gave the name "intersectionality" to a far larger and more ethnically diverse trajectory of work, now global in nature, that speaks truth to power sited differentially rather than centralized in a single locus. What could also be called intersectional analysis was in fact developing at roughly the same time among European and postcolonial feminists, including, for example, Anthias \& Yuval-Davis (1983; 1992) ; Brah (1996), Essed (1991), Ifekwunigwe (1999), Lutz (1991), Meekosha, and Min-ha (1989). 
Indeed, it seems that, in a manner parallel to that which Sandra Harding characterizes the evolution of standpoint theory, intersectionality was an idea whose time had come precisely because of the plethora of authors working independently across the globe making vastly similar sets of claims. Around the world, those interested in a more comprehensive and transformative approach to social justicewhether sociologists, legal scholars, feminist theorists, policy makers, or human rights advocates - have used the language and tenets of intersectionality to more effectively articulate injustice and advocate for positive social change.

The books in this series represent an interrogation of intersectionality at various levels of analysis. They unabashedly foreground the politics of intersectionality in a way that is designed to both honor the legacy of earlier scholarship and activism, and push the boundaries of intersectionality's value to the academy and most importantly to the world. We interpret the series title, The Politics of Intersectionality, in two general ways:

First, we emphasize the politics of intersectionality, broadly conceived; that is to say, we include debates among scholars regarding the proper conceptualization and application of the term "intersectionality" as part and parcel of the series' intellectual project. Is intersectionality a paradigm? Is intersectionality a normative political (specifically feminist) project? Is it a method or epistemological approach? Is it (merely) a concept with limited applicability beyond multiply marginalized populations? Our own idiosyncratic answers to these questions are far less important than the open dialog we seek by including them within the scholarly discourse generated by the series.

What this means pragmatically is that rather than dictatorially denote an extant definition of intersectionality and impose it on every author's manuscript, as series editors our task has been to meaningfully push each author to grapple with their own conceptualization of intersectionality and facilitate their interaction with an ever-growing body of global scholarship, policy, and advocacy work as they render such a conceptualization transparent to readers, reflexive as befits the best feminist work, and committed to rigorous standards of quality no matter the subject, the method, or the conclusions. As editors, we have taken such an active role precisely because grappling with the politics of intersectionality demands our adherence to the normative standards of transparency, reflexivity, and speaking to multiple sites of power for which intersectionality is not only known but also lauded as the gold standard. It is our honor to build this area of scholarship across false boundaries of theory and praxis; artificially distinct 
academic disciplines; and the semipermeable line between scholarship and activism.

No less importantly, we emphasize politics to mean, well, politicswhether everyday senses of justice; so-called formal politics of social movements, campaigns, elections, policy, and government institutions; or personal politics of identity, community, and activism across a broad swath of the world. While this general conceptualization of politics lends itself to the social sciences, we define social sciences in a broad way that again seeks to unite theoretical concerns (whether normative or positive) with interpretive and empirical approaches across an array of topics far too numerous to list in their entirety.

The second way we interpret the series title-simultaneously, as one might expect of intersectionality scholars-is with an emphasis on the word intersectionality. That is, the books in this series do not depend solely on 20-year-old articulations of intersectionality, neither do they adhere to one particular theoretical or methodological approach to study intersectionality; they are steeped in a rich literature of both substantive and analytical depth that in the twenty-first century reaches around the world. This is not your professor's "women of color" or "race-class-gender" series of the late twentieth century. Indeed, an emphasis on up-to-date engagement with the best and brightest global thinking on intersectionality has been the single most exacting standard we have imposed on the editing process. As series editors, we seek to develop manuscripts that aspire to a level of sophistication about intersectionality as a body of research that is in fact worthy of the intellectual, political, and personal risks taken by so many of its earliest interlocutors in voicing and naming this work.

Currently, intersectionality scholarship lacks a meaningful clearinghouse of work that speaks across (again false) boundaries of a particular identity community under study (e.g., Black lesbians, women of color environmental activists), academic disciplines, or the geographical location from which the author writes (e.g., Europe, North America, or Southeast Asia). For this reason, we expect that the bibliographies of the manuscripts will be almost as helpful as the manuscripts themselves, particularly for senior professors who train graduate students and graduate students seeking to immerse themselves broadly and deeply in contemporary approaches to intersectionality. We are less sanguine, however, about the plethora of modifiers that have emerged to somehow modulate intersectionality-whether it be intersectional stigma, intersectional political consciousness, intersectional praxis, post-intersectionality, paradigm intersectionality, or even Crenshaw's original modes of structural and political 
intersectionality. Our emphasis has been on building the subfield rather than consciously expanding the lexicon of modes and specialities for intersectionality.

Series Editors:

Ange-Marie Hancock, University of Southern California Nira Yuval-Davis, University of East London

Also in the series:

Solidarity Politics for Millennials

Ange-Marie Hancock

Social Change and Intersectional Activism: The Spirit of Social Movement

Sharon Doetsch-Kidder

Urban Black Women and the Politics of Resistance

Zenzele Isoke 


\title{
URBAN BLaCK WOMEN aND THe Politics of RESISTANCE
}

\author{
Zenzele Isoke
}

\section{palgrave macmillan}




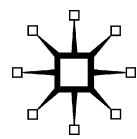

URBAN BLACK WOMEN AND THE POLITICS OF RESISTANCE

Copyright (C) Zenzele Isoke, 2013.

Softcover reprint of the hardcover 1st edition 2013 978-0-230-33903-3

All rights reserved.

First published in 2013 by

PALGRAVE MACMILLAN ${ }^{\circledR}$

in the United States-a division of St. Martin's Press LLC,

175 Fifth Avenue, New York, NY 10010.

Where this book is distributed in the UK, Europe and the rest of the world, this is by Palgrave Macmillan, a division of Macmillan Publishers Limited, registered in England, company number 785998, of Houndmills, Basingstoke, Hampshire RG21 6XS.

Palgrave Macmillan is the global academic imprint of the above companies and has companies and representatives throughout the world.

Palgrave ${ }^{\circledR}$ and Macmillan ${ }^{\circledR}$ are registered trademarks in the United States, the United Kingdom, Europe and other countries.

ISBN 978-1-349-34208-2 ISBN 978-1-137-04538-6 (eBook)

DOI $10.1057 / 9781137045386$

Library of Congress Cataloging-in-Publication Data is available from the Library of Congress.

A catalogue record of the book is available from the British Library.

Design by Newgen Imaging Systems (P) Ltd., Chennai, India.

First edition: January 2013

10987654321 
I dedicate this book to black people in the inner cities of Saint Louis, Long Beach, Detroit, North Minneapolis, East Saint Paul, and Newark. Your lives, ideas, and contributions to bumanity matter. Own that. 


\section{CONTENTS}

Preface $\quad$ xi

Acknowledgments xiii

1 Introduction 1

2 Framing Black Women's Resistance: A Black Feminist Intersectional Approach 13

3 Making Place in Newark: Neoliberalization and Gendered Racialization in a US City 37

4 (Re)Imagining Home: Black Women and the Cultural Production of Blackness in Newark 59

5 The Politics of Homemaking: Black Feminist $\begin{array}{ll}\text { Transformations of a Cityscape } & 77\end{array}$

Mobilizing after Murder: Black Women Queering
Politics and Black Feminism in Newark

7 Keepin' Up the Fight: Young Black Feminists and the Hip Hop Convention Movement

8 The Audacity to Resist: Black Women, Social Capital, and Black Cultural Production

$\begin{array}{ll}\text { Appendix } & 167\end{array}$

$\begin{array}{ll}\text { Notes } & 175\end{array}$

$\begin{array}{ll}\text { Bibliography } & 183\end{array}$

$\begin{array}{ll}\text { Index } & 199\end{array}$ 


\title{
PREFACE
}

\author{
A Word about Urban Black \\ Women AND THE Politics \\ OF RESISTANCE
}

\begin{abstract}
In the third book in this series, Urban Black Women and the Politics of Resistance, Zenzele Isoke turns our attention to an urban politics of resistance among Black women activists in Newark, New Jersey. In so doing she builds upon one of the central contributions of Kimberle Crenshaw's explication of structural intersectionality: the need for rendering the invisible visible. Isoke's work reveals the political labor of urban Black women that even in the twenty-first century is too often overlooked or subsumed under the charismatic leadership of Black male political elites. For Isoke, coalitions and community alliances are produced episodically as "assemblages" (Puar 2007) of resistance politics. However, Isoke explicitly locates that visibility through deep engagement with the city of Newark, a site the activists characterize as a "beloved city" that is most commonly viewed by outsiders as an archetype of US urban pathology. In this way her book links Black women's resistance politics to broader questions of long-term sustenance of city life.

Isoke lifts up the "life truths" of 29 activists, women she characterizes as "alchemists of resistance." These women, who "take the harshest realities of urban containment and create wellsprings of possibility for positive social action" offer practices that can expand our abilities to contend with intersecting systems of heteropatriarchy, racism, and spatial marginalization through innovative outlets like the "rant fest," an intimate public space for laughter, tears, nurturance, and catharsis. Seeking to expand our notions of politics as activism that may or may not directly involve interactions with local government, Isoke uses interpretive and qualitative methods to examine "the anatomy of two specific community mobilizations in Newark."
\end{abstract}


The first three books in the series-Solidarity Politics for Millennials, Social Change, and Intersectional Activism and now Urban Black Women and Political Resistance-have each explored various aspects of the United States as a site ripe for intersectional analysis. We look forward to a more global focus in the next two installments of the series, turning first toward Europe and then via an anthology with chapters exploring intersectional politics from a variety of global locations. As always, we welcome submissions and comments on what is becoming a very successful contribution to intersectional scholarship and activism. 


\section{ACKNOWLEDGMENTS}

This

his book is nothing less than the product of a community of people who had faith in my abilities, faith in this project, and the conviction that social justice can be more than just a socially appealing concept. First and foremost, I wish to thank my mother, Vickie M. Dunlap-Jones, my grandparents Vivian and Charlie Roberts, and my great aunties who have always loved me and encouraged me. I also thank my daughters, Folashade and Thandiwe Wilson, for their unfaltering love and patience with Mommy over the course of their young lives. I also thank Dr. Ruth Nicole Brown for her steadfast support and loving sisterhood since the journey to this book began.

I would like to extend a very humble line of gratitude to the people of the city of Newark, New Jersey. Without people like Baye Adofo-Wilson, Anthony Smith, Hashim Shomari, Monique Baptiste, Fayemi Shakur, Susu Stewart, June Dowell, Angela Garretson, Janyce Jackson, and the staff of the Lincoln Park Coast Culture District, it would have been impossible for me to have access to the range of dynamic voices featured in this book. Anthony Smith, especially, thank you for taking my hand and pressing me onward when I wavered. I also extend a note of deep appreciation to the New Jersey Information Room of the Newark Public Library for keeping such meticulous historical records on the intricacies of New Jersey.

I remember you too, Sakia.

I also thank the Department of Gender, Women, and Sexuality Studies and the College of Liberal Arts at the University of Minnesota for their support of this project through course releases, internal grants, and summer support. The Institute for Diversity, Equity, and Advocacy and the Imagine Fund at the University of Minnesota also deserves a note of thanks for their generous funding of this research. My colleagues in the Department of Gender, Women, and Sexuality Studies, African and African American Studies, American Studies, Communication Studies, the Department of Political Science, and Theatre Studies including Jigna Desai, Richa Nagar, Eden Torres, 
Dara Strolovitch, Regina Kunzel, Roderick Ferguson, Catherine Squires, Yuichi Onishiro, Walt Jacobs, and Cindy Garcia are appreciated for their warmth, candid, and insightful feedback, and encouragement of many layers of this work over the years. I also commend Brittany Lewis for her stellar summer research assistance. I also extend a note of thanks to the students in my Black Feminist Geographies classes who have made teaching such a joy: Hana Worku, Anne Wolfe, Tiffany Williams, Shayla Walker, Sherese Taylor, Fazeyeh Rose Augustus, Melody Hoffman, Carra Martinez, Pabalelo Mmila, Barbara St. Pierre, and Bailey Irie Ceesay. I also acknowledge the brilliantly unruly students of my Sex, Politics, and Hip Hop classes, especially Anna and Moira Pirsch, Shareef Omar-Taylor, Erica Deanes, and Parker Benjamin. To Ananya Chatterjea: The book is done. I am ready to dance!

I extend an extra special note of thanks and solidarity to the courageous intellectual leadership of Cathy Cohen, Barbara Smith, bell hooks, Cheryl Clarke, Barbara Ransby, Carole Boyce Davies, Leith Mullings, Beverely Guy-Sheftall, Patricia Hill Collins, Nikol Alexander-Floyd, and Katherine McKittrick. It is upon your shoulders I stand. To Kimala Price, Melynda Price, Aishah Durham, Tracy Fisher, Aimee Cox, Tiffany Willoughby, Nadia Brown, and other young academics who have fought the good fight to produce social knowledge about black women on our own terms, I salute you. I also thank my former graduate adviser, a white, middle class, capital-F, (not so) hegemonic feminist named Mary E. Hawkesworth, who showed, through her applied mentorship, that it was perfectly okay to study black women the way I wanted to study black women without having to apologize for it. Similarly, I thank Rose and Malika Sanders of the Twenty-First Century Youth Leadership Movement in Selma, Alabama, who provided me with the political space to realize and validate my own peculiar role in the protracted struggle for the liberation of people of African descent in the United States.

The organizers of the Malcolm X Grassroots Movement (MXGM) deserve special acknowledgment. It was these highly dedicated, devoted, revolutionary black nationalists who politicized me and kept my skills from being wasted in a law firm or a corporation. Truly, it is their work that keeps black freedom struggle alive in American communities. Akinyele Umoja, Ollimata Taal, Connie Tucker, Senovia Muhammud, Monifa and Lumuumba Bandele, Karl Kamao Franklin, Ijeoma Isoke, Cliff Albright, and April Englund were among my first teachers. MXGM keeps Malcolm's message of human rights, self-determination, and black love alive in communities (rural and 
urban) that other scholar activist-scholars have abandoned as they have moved on up in the academy. MXGM saves black lives everyday.

Finally, I thank my two best friends since fifth grade, Latasha Pennant and Avys Stevensen, for their loving support over the years. I could not have done it without you. To my next-door neighbors, Saba Teshome, Robel Tedros, and "Maiye," thank you for making me part of the family. An extra special thanks to the new genius in my life, Larry Louisiana. Thanks for reading every single word of this manuscript out loud so that I could hear and consider my own words.

To Mr. Barack Obama: If you get reelected, I expect you to pardon Sundiata Acoli, Assata Shakur, and Sekou Odinga. Let three of our most beloved black freedom fighters come home. They have suffered enough. 